\title{
Risk Factors Associated with Nocturia in Patients with Obstructive Sleep Apnea Syndrome
}

\author{
Mutlu Deger ${ }^{1}$, Ozgur Surmelioglu ${ }^{1}$, Sedat Kuleci ${ }^{1}$, Volkan Izol ${ }^{1}$, Nebil Akdogan ${ }^{1}$, Elvan \\ Onan $^{1}$, Ilda Tanrisever ${ }^{1}$, and Ibrahim Aridogan ${ }^{1}$ \\ ${ }^{1}$ Cukurova University Faculty of Medicine
}

July 7,2020

\begin{abstract}
Aim: To evaluate risk factors associated with nocturia in patients with obstructive sleep apnea syndrome (OSAS). Materials and Methods: Patients diagnosed with OSAS by polysomnography (PSG) and over eighteen years old evaluated retrospectively between January and December 2019. The number of nocturia episodes was assessed in the 3-day bladder diary. We analyzed age, gender, body mass index (BMI), apnea-hypopnea index (AHI) scores and severity, hypertension, diabetes mellitus, smoking, heart diseases in all patients. Results: A total of 124 patients with the mean age of $49.9 \pm 11.6$ years (range 25-81 years) was included in the study. Ninety-two $(75.8 \%)$ patients had nocturia. The mean nocturia episode of patients with nocturia was 2.4?1.3. To determine the factors that affect the risk of nocturia, logistic regression analysis was performed. The results revealed that patient age and BMI were found as the most effective risk factors determining nocturia $(\mathrm{p}<0.05)$. The odds of patient age were 1.06 (95\% CI 1.01-1.11, p=0.010) times higher for patients with nocturia. Every 1 unit increase in BMI increased the risk of nocturia by 1.12. 48 patients with nocturia underwent continuous positive airway pressure (CPAP) therapy or surgical treatment. The mean nocturia epilsodes of these patients were $2.3+-1.4$ before treatment and were $1.7+-2.2$ after treatment. There was a significant decrease in terms of nocturia episodes $(\mathrm{p}=0.032)$. Although there was a significant increase in the total daily urine volume after treatment, there was a statistically decrease in total night-time urine volume at night ( $\mathrm{p}=0.016$ and $\mathrm{p}=0.024$, respectively). Conclusion Age and BMI were risk factors associated with nocturia in patients with OSAS.
\end{abstract}

\section{Hosted file}

manuscript.docx available at https://authorea.com/users/339527/articles/467700-risk-factorsassociated-with-nocturia-in-patients-with-obstructive-sleep-apnea-syndrome

\section{Hosted file}

Table 1.docx available at https://authorea.com/users/339527/articles/467700-risk-factorsassociated-with-nocturia-in-patients-with-obstructive-sleep-apnea-syndrome

\section{Hosted file}

Table 2.docx available at https://authorea.com/users/339527/articles/467700-risk-factorsassociated-with-nocturia-in-patients-with-obstructive-sleep-apnea-syndrome

\section{Hosted file}

Figure 1.docx available at https://authorea.com/users/339527/articles/467700-risk-factorsassociated-with-nocturia-in-patients-with-obstructive-sleep-apnea-syndrome 